\title{
Model of Mars on Student Behavior and Its Effect to Learning Effectiveness
}

\author{
Prihatin Tiyanto P. $\mathrm{H}^{1^{*}}$ \\ ${ }^{\mathrm{T}}$ Faculty of Economics and Business, University of 17 August 1945 Semarang, Jl. Pemuda No.70, Pandansari, Kec. \\ Semarang Tengah, Kota Semarang, Jawa Tengah 50133, Indonesia \\ *Corresponding Author: Prihatin Tiyanto P. H \\ Faculty of Economics and Business, University of 17 August 1945 Semarang, Jl. Pemuda No.70, Pandansari, Kec. Semarang Tengah, \\ Kota Semarang, Jawa Tengah 50133, Indonesia
}

\section{Article History}

Received: 23.12.2021

Accepted: 30.01 .2022

Published: 02.02.2022

\begin{abstract}
The pandemic condition and online learning have affected Private Universities, especially student behavior. The purpose of this study was to conduct a study of the MARS model to analyze student behavior and its effect on learning effectiveness. The research was conducted on private university students in the city of Semarang, the sample was taken from the population with a purposive sampling method sampling technique as many as 150 students as respondents. The analytical tool used is SPSS with Linear Regression Method. The results showed that the MARS model had a significant influence on student behavior and had a positive and significant effect on learning effectiveness.
\end{abstract}

Keywords: Motivation, Ability, Role Perception, Situational Factors, Individual Behavior and Learning Effectiveness.

\section{INTRODUCTION}

The pandemic caused by the Covid-19 that occurred in 2019 has not yet ended, resulting in an impact in various fields of life, including in the field of education. In the field of education, many private universities and students were initially unprepared to face the pandemic. The emergence of various new regulations implemented such as health protocols, namely the application of $3 \mathrm{M}$ (Wearing Masks, Keeping Distance and Washing Hands), plus government policies, namely changing the policy of working at home or WFH from offline to virtual, resulting in many higher education institutions and students being unprepared. Therefore, this policy has an impact on student behavior and creates problems in learning effectiveness. Using the MARS Model (Motivation, Ability, Role Perception and Situational Factor) research to analyze student behavior in dealing with these conditions.

Motivation is described as an individual's psychological process to behave according to goals or act because of the passion, direction, and persistence of behavior (Campbell et al., 1970; Luthans, 1977), and the human desire to manage, control, or explain behavior (Llaci, 2012). In addition, according to (Appelbaum et al., 2000; Jiang et al., 2012), motivation is based on the assumption that individual behavior uses discretion to play the perception of the role they have and see situational factors in order to maintain activities and maintain job security. For this reason, students in addition to motivation must have the ability to adapt in emergency conditions.

Ability is a natural tendency that can be learned and is needed to complete a task successfully. 'Ability' focuses on developing students to improve their talents, skills including their competencies (Kundu, Subhash C.; Gahlawat, Neha; (2016). A good student ability means using the perception of the role they have appropriately, so that students can behave accordingly, with the conditions that occurred at the time of the emergency.

Copyright (C) 2022 The Author(s): This is an open-access article distributed under the terms of the Creative Commons Attribution 4.0 International License (CC BY-NC 4.0) which permits unrestricted use, distribution, and reproduction in any medium for noncommercial use provided the original author and source are credited. 
Role perception is used as a direction in which a person channels his efforts (Sanghi, 2011). Perception of the role is the role of the student actually independently, trying really hard where he learns. Students in learning follow various applicable regulations from the institution concerned, including at the Faculty where the student's position is carrying out their studies. Students with their positions can play their real roles, so they are able to carry out their duties properly and correctly. Therefore, it should be seen closely what the student believes in his role and at the same time, what norms he believes stand out for the role (Agnihotri and Sharma, 2011). The role as part of the assessment process accurately reflects what is required by the role so as to produce a perception of the role (Dierdorff and Morgeson, 2007). Research (Bray and Brawley, 2002; Beauchamp et al., 2002) argues that role perception (clearness or absence of role ambiguity) affects student work outcomes. The role of ambiquity can occur due to situational factors such as pandemic conditions and this creates problems in student behavior.

Situational factors, broadly speaking, refer to (a) situational cues (objective physical stimuli) in an environment, (b) psychological situation characteristics (subjective meaning and interpretation of the situation), and (c) situation class (type or group of all situations) with the same cue or similar level or profile of characteristics). Narrowly, situational factors refer to the broad dimensions of situational characteristics used to describe and compare any situation. Situational factors were found to influence behavior, including the presence of the number of students, consistency in realizing the initial learning goals (Fischer et al., 2011). Situational factors will inevitably influence behavior (Lefevor, Fowers, Ahn, Lang, \& Cohen, 2015).

Human behavior is a complex subject, closely related to the ways and reasons behind actions. There are many theories of human behavior and different types of behavior. Understanding human behavior is very important to science; because it can explain patterns, the reasons people make certain decisions, so that they can position themselves and understand how people see, interpret, and adapt to various environments. Individual behavior can be limited by the response mix due to the presence of external and internal stimuli. Individual behavior is defined the way a person reacts in different situations and expresses different emotions like anger, happiness, love, etc. In Behavioral Change Theory, it refers to "attitude" which is about a person's beliefs towards certain behavioral attitudes (Ajzen, I., \& Fishbein, M. (2005). Integrative Behavioral Model (Fishbein, M. \& Cappella, JN (2006) emphasizes that, any particular behavior is most likely to occur if a person has a strong intention to perform, has the skills and abilities necessary to perform the behavior, and there are no environmental or other constraints to prevent the behavior.

According to (Signe Schack Noesgaard, and Rikke rngreen; 2015), that the use of e learning, artifacts (eLearning solutions) find resources, individual motivation and experience affect learning effectiveness. Learners' attitudes toward blended learning can result in learning effectiveness and shape behavioral intentions that typically lead to persistence in an inclusive, mixed learning environment. Selim, (2007) noted that the attitude of learners towards elearning and blended learning is a success factor for the learning environment. Selim (2007) describes three main factors that influence e-learning and the effectiveness of blended learning as characteristics of instructors, technology and student characteristics. This study aims to prove that the MARS model will affect individual behavior and have an impact on the effectiveness of student learning.

\title{
LITERATURE REVIEW Motivation
}

Motivation can be described as an internal force that influences the direction, intensity, and endurance of a person's voluntary behavioral choices. Motivation includes; Direction - focused on the goal; Intensity - best effort to use; Persistence - the amount of time it takes for the effort put in; and the human desire to manage, control, or explain behavior (Llaci, 2012). Researchers and education practitioners in particular reveal that motivation is one of the most important factors in student achievement as well as ensuring sustainable achievement (Alkış 2015; Aluçdibi and Ekici 2012). The concept of motivation is considered an important factor influencing human behavior and performance (Kian et al., 2014; Turan 2015).

\begin{abstract}
Ability
Ability is a natural tendency that can be learned and is needed to complete a task successfully and successfully. Ability generally has four indicators, namely; one is talent - which can help people learn more efficiently and perform effectively, second is the ability to learn - concerning the skills and knowledge possessed so that goals are easily achieved; third competence - includes individual values, personality traits and other features of the individual so as to produce superior performance; and fourth is people-to-work fit - there are three ways to match people to work; including selecting people who are qualified, willing to practice, redesigning jobs to match abilities. Robbins and Judge (2011) state that ability is an individual's capacity to perform various tasks in a job. Furthermore, Kreitner and Kinicki (2014) state ability as a stable characteristic related to a person's maximum physical and mental abilities. This is evidenced by a person in completing a task quickly and precisely in accordance with the method or standard that is manifested in the implementation of his duties.
\end{abstract}




\section{Role Perception}

Human role perception is the belief about what behavior is required to achieve the desired results, and clearly examines the duties and responsibilities of the job. Indicators of the role of perception include four things, namely, understanding the task to be carried out, understanding the importance of the task given; understand the appropriate actions to complete each task; and clarifying role perceptions. Role perception is critical to decision making; (Singh H C and Kumar R 2012). Perception of the role can provide an accurate assessment reflects what is required by the perception of the role (Dierdorff and Morgeson, 2007). Therefore, the role perception will find norms that are believed to stand out for behavioral activities that are appropriate for the role (Agnihotri and Sharma, 2011).

\section{Situational Factor}

Personality variables are often not appropriate at the beginning to predict individual behavior, because it turns out that there is a difference between what is expected and the existing reality. Therefore Mischel (1968) suggests considering situational factors to make predictions that cause behavioral differences. Mischel's observations, through hundreds of studies by examining the relationship between various situational factors and spontaneous helping behavior that are carried out lead to short-term results (hereinafter referred to as helping behavior). Many situational factors were found to influence helping behavior, including reasons for the number of events attended (Fischer et al., 2011), mood, ambiguity of the situation, perceived deviation from the person requiring help, noise, temperature G. Tyler Lefevor, Blaine J .Fowers (2016). The study results, taken together, explain the undeniable impact of situational factors on helping behavior (Lefevor, Fowers, Ahn, Lang, \& Cohen, 2015). Situational factors are factors that individuals cannot control and occur spontaneously, usually limited by a narrow time and short term for action (John F. Rauthmann; 2017).

\section{Individual Behavior}

Individual behavior can be defined as a mixture of responses to external and internal stimuli. Individual behavior occurs because of the initial intention or the way a person reacts in different situations and the way how a person expresses different emotions such as anger, happiness, love, etc. Individual behavior is important to know why someone takes certain actions so that they know the exact reasons when individuals make behavioral decisions. Behavior change occurs when defining habit formation, so individual behavior is defined as an effort to encourage training and repetition of behavior in the same context so that behavior emerges (Michie et al., 2013). Thus the behavioral indicator variables include the presence of intentions, individuals express themselves, individuals have behavioral patterns, choose reasons to act, and make behavioral decisions (Michie et al., 2013).

\section{Learning Effectiveness}

Learning is a reflective activity that allows students to utilize previous experiences to understand and evaluate the present, thereby shaping future actions and formulating new knowledge Abbott J (1994). Meanwhile, effectiveness is an assessment made in relation to individual achievement, so that the more accomplished students are expected to be closer to the standard or exceeding the achievement standard, the more effective it is considered (Gibson et al., 2013). Thus, learning effectiveness can be defined as the reflective ability of students to take advantage of previous experiences and be able to evaluate current activities so as to form new knowledge for the future and towards standards or exceeding the standards set. Indicators of effective learning include - more connected knowledge, conduct purposeful learning, selfability to be goal-directed, have reflective abilities, have a vision of the future about learning, have positive emotions and affiliations to learn, have broad strategies and understand understanding complexity. In the teaching and learning process, there are many factors that influence the success of a lesson, including curriculum, absorption, teacher presence, student attendance and learning achievement. However, in this study, it is seen through the seriousness of students in seeking success in learning.

\section{Hypothesis \\ a. The Relationship of Motivation to Student Behavior}

The concept of motivation is considered an important factor influencing human behavior and performance (Kian et al., 2014; Turan 2015). Researchers and education practitioners in particular reveal that motivation is one of the most important factors in student achievement and in ensuring sustainable achievement (Alkış 2015; Aluçdibi and Ekici 2012). Regardless of the type of motivation (intrinsic motivation and extrinsic motivation), additional components of motivation provide clues about the nature of individual motivation. Some of these components are directly related to individual academic achievement; as intrinsic goal orientation, while extrinsic goal orientation such as subject grades, control of learning beliefs, independence and test anxiety (Aktan and Tezci 2013; Bates et al., 2016). The study (Deepika Sharma and Sushma Sharma, 2018) concluded that the research findings justify the importance of self-concept and motivation for academic achievement, and some recommendations have been made regarding improving motivation and self-concept. Thus motivation is very influential on individual behavior.

\section{H1: Motivation has a positive effect on student behavior.}




\section{b. Relationship between Ability and Student Behavior}

Human resources with high capabilities strongly support the organization's vision and mission to develop rapidly. Skilled people will be different from people who have average or normal abilities. Robbins and Judge (2011) state that ability is an individual's capacity to perform various tasks in a job. Furthermore, Kreitner and Kinicki (2014) state ability as a stable characteristic related to a person's maximum physical and mental abilities. This is evidenced by a person in completing a task quickly and precisely in accordance with the method or standard that is manifested in the implementation of his duties. Devonish and Greenidge (2010) prove the role of role-based-ability on employee performance. Companies provide different jobs that require employees to give up abilities. Kundu, Subhash C.; Gahlawat, Neha (2016). Using primary data from 563 employees from 204 companies operating in India (collected during the period March 2012 and January 2013), it shows that increased capability, increased motivation, and improved human resource practices result in increased affective commitment and superior company performance or intellectual opportunities. Thus it can be stated that individual abilities will affect individual behavior.

\section{H2: Ability has a positive influence on student behavior}

\section{c. Motivation has an Influence on Student Behavior in Mediating Role Perception}

Most decisions are based on individual perceptions and their conclusions. The perception of its role and contribution is very important when considering alternatives for the basis of decisions to be made by an individual's intuition and beliefs; (Caio Cesar Lima and Diego Canbarro; 2015). Perception of role is very important for decision making; (Singh H C and Kumar R 2012). Motivation Part of the process that involves the outcome of the role perception and assessment that accurately reflects what is required by the role perception (Dierdorff and Morgeson, 2007). Therefore, it is necessary to look closely at what the actor believes in his role and at the same time, what norms he believes stand out for his behavioral activities according to his role (Agnihotri and Sharma, 2011). Thus, role perception can mediate motivation towards behavior.

\section{H3: Motivation has an influence on Student Behavior in Mediating Role Perception}

\section{d. Ability to have an influence on student behavior in situational factor mediation}

Following Mischel's observations, hundreds of studies have investigated the relationship between various situational factors and spontaneous helping behavior in short-term exchanges (helping behavior), many situational factors were found to identify behaviors, including the number present (Fischer et al., 2011), mood heart, ambiguity, bondage, deviation. This study explains the undeniable impact of situational factors on behavior (Lefevor, Fowers, Ahn, Lang, \& Cohen, 2015). More narrowly, situational factors refer to the broad dimensions of situation characteristics used to describe and compare any situation (John F. Rauthmann; 2017). Behavioral changes occur when forming habits as an effort to encourage training, repetition of behavior in the same context over and over again so that behavior emerges (Michie et al., 2013). Thus situational factors can mediate the ability of student behavior.

\section{H4: Ability to have an influence on student behavior in situational factor mediation}

\section{e. The influence of individual behavior on the effectiveness of student learning}

According to (Noesgaard S. S. and rngreen R 2015), the definition of learning effectiveness involves two things, namely learning outcomes, learning transfer. The criteria for effective learning and measures of the effectiveness of effective learning must be consistent. Studies (Tang C M and Chaw L Y, 2016) provide evidence that digital literacy is a prerequisite for students to be effective in learning in a blended learning environment. Thus there is the influence of individual behavior due to motivation and ability on the effectiveness of student learning. A learner's attitude towards blended learning can result in its effectiveness and this forms behavioral intentions that usually lead to persistence in an inclusive, mixed learning environment. Selim, (2007) notes that the learner's attitude towards e-learning and blended learning is a success factor for this learning environment. Selim (2007) describes three main factors that influence elearning and the effectiveness of blended learning as characteristics of instructors, technology and student characteristics. Student performance by age and gender in e-learning and blended learning has been found to show no significant differences between male and female learners and different age groups (i.e. young, middle-aged and older than 45 years) (Coldwell, Craig, Paterson, \& Mustard, 2008). This implies that the mixed learning potential is effective and is not hindered by gender or age differences.

H5: Individual behavior has a positive effect on the effectiveness of student learning. 


\section{Research Framework}

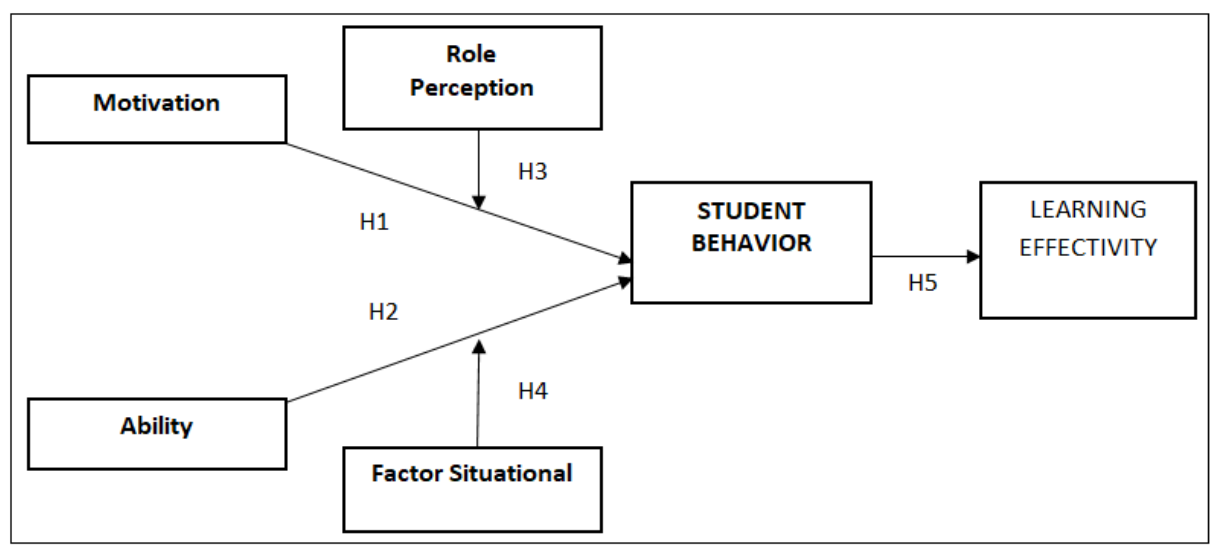

Figure 1: Model of MARS on Student Behavior

\section{RESEARCH METHOD}

\section{Population and Sample}

The population is all PTS students in the city of Semarang. In this study, taken from 3 private universities in the city of Semarang, namely Dian Nusantara University Semarang, Untag Semarang and Wahid Hasyim University Semarang. Each PTS was taken with a purposive sampling technique, 50 students were taken from each PTS, a total of 150 students were obtained. Data were collected by questionnaire using google form and email where the researcher was involved as a teacher at the three private universities concerned, respondents were asked for responses within a period of 3 months, namely October, November and December, 2021. All indicator variables were measured using a Likert scale from a scale of 1 disagree to a scale of 5 strongly agree. Previously, the instrument was tested with validity and reliability tests and no problems could be identified.

Operational Variabel and Indicators

\begin{tabular}{|c|c|c|}
\hline OperationalVariabel & Indicators and Instruments & Reference \\
\hline $\begin{array}{l}\text { Motivation: } \\
\text { Motivation can be described } \\
\text { as an internal force that } \\
\text { influences direction, } \\
\text { intensity, and endurance and } \\
\text { the persistence and ability to } \\
\text { manage one's voluntary } \\
\text { behavioral choices. }\end{array}$ & $\begin{array}{l}\text { Passion, - students have a strong passion to complete their studies. } \\
\text { Direction, - students have a clear direction to complete the study. } \\
\text { Persistence of behavior - Students have persistence to complete their } \\
\text { studies. } \\
\text { Intensity - Students have more frequency of completing studies. } \\
\text { 5. Behavior management - Students have better behavior control. }\end{array}$ & $\begin{array}{l}\text { (Campbell et } \\
\text { al., 1970; } \\
\text { Luthans, 1977); } \\
\text { (Llaci, 2012). }\end{array}$ \\
\hline $\begin{array}{l}\text { Ability: } \\
\text { Ability is a natural tendency } \\
\text { that can be learned and is } \\
\text { needed to complete a task } \\
\text { successfully. }\end{array}$ & $\begin{array}{l}\text { Talent - Students have a natural talent to help study more efficiently } \\
\text { and perform effectively. } \\
\text { Skills learned - Students use their skills and knowledge to learn. } \\
\text { Competence - students possess individual values, personality traits } \\
\text { and other features that lead to superior performance. } \\
\text { people-to-work fit - Students feel right with their field of study. }\end{array}$ & $\begin{array}{l}\text { (Kundu, } \\
\text { Subhash C.; } \\
\text { Gahlawat, } \\
\text { Neha, 2016). }\end{array}$ \\
\hline $\begin{array}{l}\text { Role Perception } \\
\text { beliefs about what behaviors } \\
\text { are needed to achieve the } \\
\text { desired results, and have the } \\
\text { ability to precisely examine } \\
\text { the actual role according to } \\
\text { the position occupied to } \\
\text { complete according to the } \\
\text { task. }\end{array}$ & $\begin{array}{l}\text { Understanding the Task - Understanding the task to be performed. } \\
\text { Importance of task - Understand the importance of the given task. } \\
\text { Understand the behavior - Understand the preferred behavior to } \\
\text { complete each task. } \\
\text { Clarifying role perceptions- Students are able to explain their role } \\
\text { perceptions. }\end{array}$ & $\begin{array}{l}\text { (Sanghi, 2011) } \\
\text { (Pankaj Kumar, } \\
\text { Dr Prabhjot } \\
\text { Kaur, Dr R K } \\
\text { Kalra, 2013) }\end{array}$ \\
\hline $\begin{array}{l}\text { Situational Factor } \\
\text { Situational factors are } \\
\text { environmental factors } \\
\text { beyond the control of } \\
\text { behavior that cause }\end{array}$ & $\begin{array}{l}\text { Attendance - Students understand the importance of attendance. } \\
\text { Mood - Students are active when the mood is supportive. } \\
\text { Deviation of situation - Student activities often experience deviation } \\
\text { of situation. } \\
\text { Ambiquity of the situation - Students when doing activities often }\end{array}$ & $\begin{array}{l}\text { (Fischer, P., } \\
\text { Krueger, J. I., } \\
\text { Greitemeyer, } \\
\text { T., Vogrincic, } \\
\text { C., }\end{array}$ \\
\hline
\end{tabular}




\begin{tabular}{|c|c|c|}
\hline OperationalVariabel & Indicators and Instruments & Reference \\
\hline $\begin{array}{l}\text { spontaneous action in the } \\
\text { short term (hereinafter } \\
\text { referred to as helping } \\
\text { behavior to behave). }\end{array}$ & experience ambiguity. & $\begin{array}{l}\text { Kastenmüller, } \\
\text { A., Frey, D., ... } \\
\text { Kainbacher, } \\
\text { M.; 2011). } \\
\text { Lefevor, } \\
\text { Fowers, Ahn, } \\
\text { Lang, \& } \\
\text { Cohen, 2015). }\end{array}$ \\
\hline $\begin{array}{l}\text { Individual Behavior } \\
\text { The way a person reacts in } \\
\text { different situations and } \\
\text { expresses different emotions } \\
\text { like anger, happiness, love, } \\
\text { thus taking action }\end{array}$ & $\begin{array}{l}\text { Intention, - students in carrying out an action on the basis of } \\
\text { intention. } \\
\text { Self-expression - In doing the action is often expressed openly. } \\
\text { Pattern, - Students in doing something action based on the same } \\
\text { pattern. } \\
\text { Reasons to act - Students have strong reasons to take action. } \\
\text { Behavioral decisions- In difficult conditions students still make } \\
\text { behavioral decisions. }\end{array}$ & $\begin{array}{l}\text { (Michie et al., } \\
\text { 2013) }\end{array}$ \\
\hline $\begin{array}{l}\text { Student Learning } \\
\text { Effectiveness } \\
\text { Effectiveness Learning is a } \\
\text { reflective activity that allows } \\
\text { students to use previous } \\
\text { experiences to understand } \\
\text { and evaluate the present, } \\
\text { thereby shaping future } \\
\text { actions and formulating new } \\
\text { knowledge. }\end{array}$ & $\begin{array}{l}\text { Knowledge -Students More connected knowledge. } \\
\text { Purposeful - Students improve actions that are appropriate to the } \\
\text { purpose and context. } \\
\text { Positive affiliation for learning - Students have positive affiliation in } \\
\text { learning. } \\
\text { A more reflective approach - Students in learning use a reflective } \\
\text { approach. } \\
\text { Vision - students have a more developed vision of their future self as } \\
\text { learning. }\end{array}$ & Abbott J (1994) \\
\hline
\end{tabular}

Source: Various sources with modifications

\section{Analysis Techniques}

The analysis technique in this study is Path Analysis to determine the direct or indirect effect of the independent variable on the dependent variable.

Model Equation 1 Multiple Linear Regression: $\mathrm{IB}=1 \mathrm{MO}+2 \mathrm{ABI}+3 \mathrm{RP}+$

Equation 2 Multiple Linear Regression Model: $\mathrm{IB}=1 \mathrm{MO}+2 \mathrm{ABI}++3 \mathrm{SF}+$

Equation model 3: ILE $=\mathrm{a}+\mathrm{IB}+\mathrm{e}$

\section{RESULT}

Table-1: Karl Pearson Coefficient of Correlation

\begin{tabular}{|l|l|l|l|l|l|l|}
\hline VARIABLE & MOT & ABI & ROLEP & FACTS & IBEH & STDLEF \\
\hline INDICATOR & & & & & & \\
\hline MOT1 & $.602^{* *}$ & & & & & \\
\hline MOT2 & $.569^{* *}$ & & & & & \\
\hline MOT3 & $.576^{* *}$ & & & & & \\
\hline MOT4 & $.372^{* *}$ & & & & & \\
\hline MOT5 & $.384^{* *}$ & & & & & \\
\hline ABI1 & & $.715^{* *}$ & & & & \\
\hline ABI2 & & $.729^{* *}$ & & & & \\
\hline ABI3 & & $.533^{* *}$ & & & & \\
\hline ABI4 & & $.565^{* *}$ & & & & \\
\hline ROLEP1 & & & $.679^{* *}$ & & & \\
\hline ROLEP2 & & & $.789^{* *}$ & & & \\
\hline ROLEP3 & & & $.559^{* *}$ & & & \\
\hline ROLEP4 & & & $.626^{* *}$ & & & \\
\hline FACTS1 & & & & $.532^{* * *}$ & & \\
\hline FACTS2 & & & & $.621^{* *}$ & & \\
\hline FACTS3 & & & & $.552^{* * *}$ & & \\
\hline FACTS4 & & & & $.572^{* * *}$ & & \\
\hline
\end{tabular}




\begin{tabular}{|l|l|l|l|l|l|l|}
\hline VARIABLE & MOT & ABI & ROLEP & FACTS & IBEH & STDLEF \\
\hline IBEH1 & & & & & $.590^{* *}$ & \\
\hline IBEH2 & & & & & $.627^{* *}$ & \\
\hline IBEH3 & & & & & $.589^{* *}$ & \\
\hline IBEH4 & & & & & $.351^{* *}$ & \\
\hline IBEH5 & & & & & $413^{* *}$ &. \\
\hline STDLEF1 & & & & & & $.573^{* *}$ \\
\hline STDLEF2 & & & & & & $.679^{* *}$ \\
\hline STDLEF3 & & & & & & $.579^{* *}$ \\
\hline STDLEF4 & & & & & $.408^{* *}$ \\
\hline STDLEF\% & & & & & $399^{* *}$ \\
\hline **. Correlation is significant at the 0.01 level (2-tailed). & \\
*. Correlation is significant at the 0.05 level (2-tailed). \\
\hline
\end{tabular}

Note: $\mathrm{MOT}=$ Motivation, ABI $=$ Ability, ROLEP $=$ Role Perception, FACTS $=$ Factor Situasional, IBEH= Individual Behavior, STDLEF = Student Learning Effectivity.

Table reliability

Table-2: Reliability Test

\begin{tabular}{|l|l|l|}
\hline Item & Cronbach's Alpha & Description \\
\hline MOT & .680 & Reliable \\
\hline ABI & .673 & Reliable \\
\hline ROLEP & .674 & Reliable \\
\hline FACTS & .709 & Reliable \\
\hline IBEH & .724 & Reliable \\
\hline STDLEF & .714 & Reliable \\
\hline
\end{tabular}

Source: Primary Data processed 2021

Table-3: F Test Equation 1. ANOVA ${ }^{\text {b }}$

\begin{tabular}{|l|l|l|l|l|l|}
\hline Model & Sum of Squares & df & Mean Square & F & Sig. \\
\hline Regression & 40.423 & 3 & 13.474 & 6.293 & $000^{\mathrm{a}}$ \\
\hline Residual & 312.617 & 146 & 2.141 & & \\
\hline Total & 353.040 & 149 & & & \\
\hline $\begin{array}{l}\text { a.Predictors: (Constant), Role Perception, Motivasi, Ability } \\
\text { b.Dependent Variable: Individual Behavior }\end{array}$ \\
\hline
\end{tabular}

Table-4: Result For Equation 1 Dependent Variable Individual behavior and Role Perception as mediating varible

\begin{tabular}{|l|l|l|l|}
\hline Variable & Cooefficient & Significant value & Hyphotesis \\
\hline ABI to IBEH & -.168 & .045 & Accepted \\
\hline MOT to IBEH & -.172 & .033 & Accepted \\
\hline ROLEP to IBEH & -.161 & .049 & Accepted \\
\hline
\end{tabular}

Source: Primary Data processed 2021

Table-5: F Test Equation 2. ANOVA ${ }^{\text {b }}$

\begin{tabular}{|l|l|l|l|l|r|}
\hline Model & Sum of Squares & df & Mean Square & F & Sig. \\
\hline Regression & 41.871 & 3 & 13.957 & 6.549 & $000^{\mathbf{a}}$ \\
\hline Residual & 311.169 & 146 & 2.131 & & \\
\hline Total & 353.040 & 149 & & & \\
\hline $\begin{array}{l}\text { a.Predictors: (Constant), Factor Situasional, Motivasi, Ability } \\
\text { b.Dependent Variable: Individual Behavior }\end{array}$ \\
\hline
\end{tabular}

Table-6: Result For Equation 2 Dependent Variable Individual behavior and Factor Situasional as mediating varible

\begin{tabular}{|l|l|l|l|}
\hline Variable & Cooefficient & Significant value & Hyphotesis \\
\hline ABI to IBEH & -.209 & .010 & Accepted \\
\hline MOT to IBEH & -.204 & .013 & Accepted \\
\hline FACTS to IBEH & -.170 & .033 & Accepted \\
\hline
\end{tabular}

Source: Primary Data processed 2021 
The influence of individual behavior on learning effectiveness

Table-7: F Test Equation 3. ANOVA ${ }^{\text {b }}$

\begin{tabular}{|l|l|l|l|l|l|}
\hline Model & Sum of Squares & df & Mean Square & F & Sig. \\
\hline Regression & 14.717 & 1 & 14.717 & 3.856 & $051^{\text {a }}$ \\
\hline Residual & 564.777 & 148 & 3.816 & & \\
\hline Total & 579.439 & 149 & & & \\
\hline $\begin{array}{l}\text { a. Predictors: (Constant), Individual Behavior } \\
\text { b. Dependent Variable : Student Learning Effectivity }\end{array}$ \\
\hline
\end{tabular}

Table-8: Result for Equation 3 Dependent Variable Student Learning Effectivity

\begin{tabular}{|l|l|l|l|}
\hline Variable & Cooefficient & Significant value & Hyphotesis \\
\hline IBEH to STDLEF & .159 & .051 & Accepted \\
\hline \multicolumn{2}{|r}{ Source: Primary Data processed 2021 } \\
\hline
\end{tabular}

Source: Primary Data processed 2021

Based on the table above, the first equation model of significance with a value of 0.000 is less than 0.05 , so it can be concluded that the regression model is appropriate and significant.

Likewise, the second equation model also has a significance value of 0.000 less than 0.05 , so it can be concluded that the regression equation model is correct and significant.

For the third equation model, the significant value of 0.051 is equal to the value of 0.05 so that the regression model is considered appropriate and significant.

The first equation follows the model of individual behavior influenced by motivation and ability with the variable role of perception as a mediating variable. With the following equation model: IBEH = -.168 MOT -.172ABI .161 ROLEP $+\varepsilon$

The second equation follows the behavioral model influenced by motivation and ability with situational factors as mediating variables. With the following equation model: $\mathrm{IBEH}=-.209 \mathrm{MOT}-.204 \mathrm{ABI}-170+\varepsilon$

The third model of individual behavior variables have a significant effect on the effectiveness of student learning. With the following Equation model: $\mathrm{STDLEF}=0.159 \mathrm{IBEH}+\varepsilon$

\section{Model Interpretation}

The results of regression equation can be interpreted as follows

Equation model 1

a. Motivation has an effect on individual behavior but has a negative value on individual behavior with a value of -

0.168 . b. Ability affects individual behavior but has a negative value on individual behavior with a value of -0.172 .

c. Role Perception Affects individual behavior but has a negative value on individual behavior with a value of -

0.161. d. Mediation effect $(-0.168 \mathrm{x}-0.161)+(-0.168)=-0.141$.

Equation model 2

a. Motivation has an effect on individual behavior but has a negative value on individual behavior with a value of 0.209 . b. Ability affects individual behavior but has a negative value on individual behavior with a value of -0.204 .

c. The Role of Situational Factors Affects individual behavior but has a negative value on individual behavior with a value of -0.170 . Mediation Effect $(-0.209 \mathrm{x}-0.170)+(-0.209)=-0.173$.

Equation model 3

Individual Behavior Variables have a positive and significant effect on the effectiveness of student learning with a value of +0.159 .

\section{DISCUSSION}

\section{a. The Relationship between Motivation and Student Behavior}

Motivation has an effect on individual behavior but has a negative value on individual behavior with a value of - 0.168. Motivation is one of the most important factors in student achievement and in ensuring sustainable achievement (Alkış 2015; Aluçdibi and Ekici 2012). The concept of motivation is considered an important factor influencing human behavior and performance (Kian et al., 2014; Turan 2015). In this study, it turns out that motivation has a significant influence, but has a negative value because according to (Bates et al., 2016) there are connected components that cause 
students to have inappropriate motivation; such as decreased enthusiasm for learning due to pandemic conditions which resulted in policy changes and a further impact on the persistence of student behavior to complete studies, the follow-up impact had an influence on the overall behavior of students. Thus, it can be concluded that under normal conditions motivation has a positive influence on behavior, but during emergency conditions such as the COVID-19 pandemic, motivation still has an effect, but several indicator variables cause the overall results to have a negative behavioral effect.

\section{b. Relationship between Ability and Student Behavior}

Ability affects individual behavior but has a negative value on individual behavior with a value of -0.172 . Robbins and Judge (2011) state that ability is an individual's capacity to perform various tasks in a job. Furthermore, Kreitner and Kinicki (2014) state ability as a stable characteristic related to a person's maximum physical and mental abilities. Skilled people are different from people who have average or normal abilities. In abnormal conditions, the individual's ability to decrease. The ability of students to use skills and knowledge is carried out by discussing and working with study groups during normal conditions, but due to the pandemic conditions students cannot study together, this causes the ability to decrease. The competence of private university students with their values and personality prefers to interact a lot with fellow students. Thus according to (Kundu, Subhash C.; Gahlawat, Neha (2016), students lose the opportunity to understand their real abilities due to lack of interaction with other students. Thus, it can be concluded that under normal conditions, student abilities have a positive effect on student behavior, but in normal conditions, student abilities have a positive effect on student behavior. The covid -19 pandemic has a negative effect on student ability, so it has a decreasing effect on behavioral values.

\section{c. Motivation has an Influence on Student Behavior in Mediating Role Perception}

Motivation has an effect on individual behavior but has a negative value on individual behavior with a value of -0.168 . b. Ability affects individual behavior but has a negative value on individual behavior with a value of -0.172 . c. Role Perception Influences on individual behavior but has a negative value on individual behavior with a value of 0.161. ; with mediating effect -0.141 . Though most decisions are based on individual perceptions and their conclusions. The perception of its role and contribution is very important when considering alternatives for the basis of decisions to be made by an individual's intuition and beliefs; (Caio Cesar Lima and Diego Canbarro; 2015), (Singh H C and Kumar R 2012). Motivation Part of the process that involves the outcome of the role perception and assessment that accurately reflects what is required by the role perception (Dierdorff and Morgeson, 2007). When students understand assignments, the importance of assignments, understand their activities, but during a pandemic, students are not able to fully explain their perception of their role. This is of course due to policy changes, such as from face-to-face to online. Students unpreparedness will result in student behavior. However, role perceptions are able to mediate motivation towards behavior even though they have negative values, but the role of mediating role perceptions is better than situational factors.

\section{d. Ability to have an influence on student behavior in situational factor mediation}

Motivation has an effect on individual behavior but has a negative value on individual behavior with a value of -0.209 . b. Ability affects individual behavior but has a negative value on individual behavior with a value of -0.204 . c. The Role of Situational Factors Affects individual behavior but has a negative value on individual behavior with a value of -0.170 and a mediating effect of -0.173 .

Following Mischel's observations, hundreds of studies have examined the linking of various situational factors in spontaneous helping behavior to short-term exchanges (called helping behavior). Many situational factors were found to identify behavior, including the amount present (Fischer et al., 2011), mood, ambiguity, bonding, deviance. This study explains the undeniable impact of situational factors on behavior (Lefevor, Fowers, Ahn, Lang, \& Cohen, 2015). More narrowly, situational factors may refer to the broad dimensions of situational characteristics used to describe and compare any situation (John F. Rauthmann; 2017). Changes in behavior form habits as an effort to encourage training, repetition of behavior in the same context so that behavior emerges (Michie et al., 2013). Thus situational factors can mediate the ability of student behavior. In this study, situational factors that influence virtual attendance, as well as mood during virtual lectures. However, what is very influential but less favorable for student behavior is the occurrence of situational deviations and situational ambiguity which causes the value of role perception to be negative.

\section{e. The influence of individual behavior on the effectiveness of student learning}

The individual behavior variable has a positive and significant effect on the effectiveness of student learning with a value of +0.159 . According to (Noesgaard S. S. and rngreen R 2015), the definition of learning effectiveness involves two things, namely learning outcomes, learning transfer. The criteria for effective learning and measures of the effectiveness of effective learning must be consistent. Studies (Tang C M and Chaw L Y, 2016) provide evidence that digital literacy is a prerequisite for students to be effective in learning in a blended learning environment. Thus there is the influence of individual behavior due to motivation and ability on the effectiveness of student learning. A learner's attitude towards blended learning can result in its effectiveness and this forms behavioral intentions that usually lead to 
persistence in an inclusive, mixed learning environment. Selim, (2007) noted that the attitude of learners towards elearning and blended learning is a success factor for the learning environment. Selim (2007) describes three main factors that influence e-learning and the effectiveness of blended learning as characteristics of instructors, technology and student characteristics. In this study, the effect of learning effectiveness on positive affiliation indicators for learning, and students using a reflective approach. Thus, individual behavior on effectiveness has a positive and significant influence.

\section{CONCLUSION}

1. The first model, namely Motivation, Ability and Role Perception, has an influence on individual behavior, although the three variables have negative values. This is acceptable because of the emergency conditions, namely the COVID-19 pandemic, which has not yet ended. This implies that motivation, ability and role perception can be useful in explaining the reasons for student behavior. In an emergency situation, students need sufficient time to be able to adapt why this behavior must be done.

2. The second model, namely motivation, ability and situational factors have an influence on individual behavior, although the three variables have negative values. This is acceptable because of the emergency conditions, namely the COVID-19 pandemic, which has not yet ended. This implies that motivation, abilities and situational factors can be useful to strengthen the explanation of why the behavior is carried out by students, in an emergency situation students need a clear understanding of the situation at hand so that they can adjust the behavior taken in dealing with certain situations.

3. The third model of Individual Behavior has a positive and significant effect on the effectiveness of student learning. This explains that the MARS model is appropriate to explain student behavior in terms of motivation, ability, perceived role and situational factors and their impact on the effectiveness of student learning.

\section{Future Research Agenda}

In future research, it is necessary to add information technology variables because of changes in the procedures for the learning system from off line to on line. However, this study did not include Information Technology variables because this study only aims to determine the MARS model on student behavior and its impact on learning effectiveness, so that information technology variables are not used.

\section{Research Limitations}

This study does not include information technology variables as intervening variables even though the research was carried out under abnormal conditions, namely a pandemic, and all teaching and learning processes were carried out with on-line or virtual systems.

\section{REFERENCE}

- Campbell, J. P., Dunnette, M. D., Lawler, E. E., III, \& Weick, K. E., Jr. (1970). Managerial behavior, performance, and effectiveness. New York, NY: McGraw-Hill.

- $\quad$ Luthans, F. (1977). Organizational behavior. New York, NY: McGraw-Hill.

- Llaci, S. (2012). Corporate governance. Remuneration of managers in corporate. Tirane, Albania: albPAPER.

- Appelbaum, E., Bailey, T., Berg, P., \& Kalleberg, A. (2000). Manufacturing advantage: Why high-performance work systems pay off. Ithaca, NY: Cornell University Press.

- Jiang, K., Lepak, D. P., Hu, J., \& Baer, J. C. (2012). How does human resource management influence organizational outcomes? a meta-analytic investigation of mediating mechanism. Academy of Management Journal, 55, 1264-1294. doi:10.5465/amj.2011.0088.

- Kundu, S. C., \& Gahlawat, N. (2018). Ability-motivation-opportunity enhancing human resource practices and firm performance: Evidence from India. Journal of Management \& Organization, 24(5), 730-747.

- $\quad$ Sanghi, S. (2011). Human resource management. Pp 138, 297. Macmillan publishers India Ltd., Delhi.

- Agnihotri, S., \& Sharma, S. K. (2011); Role Perception of Administrators and Politicians: A Study of Himachal Pradesh. Himachal Pradesh Uni J, 2, 1-12.

- Dierdorff, E. C., \& Morgeson, F. P. (2007). Consensus in work role requirements: The influence of discrete occupational context on role expectations. Journal of Applied Psychology, 92(5), 1228-1241.

- Bray, S. R., \& Brawley, L. R. (2002). Role efficacy, role clarity and role performance effectiveness. Small Group Research, 33(3), 233-253.

- Beauchamp, M. R., Bray, S. R., Eys, M. A., \& Carron, A. V. (2002). Role ambiguity, role efficacy and role performance: Multidimensional and meditational relationship within interdependent sport teams. Group Dynamics, 6(3), 229-242.

- $\quad$ Fischer, P., Krueger, J. I., Greitemeyer, T., Vogrincic, C., Kastenmüller, A., Frey, D., ... Kainbacher, M. (2011). The bystander-effect: A meta-analytic review on bystander intervention in dangerous and non-dangerous emergencies. Psychological Bulletin, 137, 517-537. http://dx.doi.org/10.1037/a0023304 
- Lefevor, G. T., Fowers, B. J., Ahn, S., Lang, S., \& Cohen, L. (2015). Helping behavior reinvisioned: A metaanalysis of decades of situational psychology research. Unpublished manuscript.

- Ajzen, I., \& Fishbein, M. (2005). The influence of attitudes on behavior. In D. Albarracín, B. T. Johnson, \& M. P. Zanna (Eds.), The handbook of attitudes (pp. 173-221). Mahwah, NJ: Erlbaum.

- Fishbein, M., \& Cappella, J. N. (2006). The Role of Theory in Developing Effective Health Communications. Journal of Communication, 56, S1-17.

- Noesgaard, S. S., \& Ørngreen, R. (2015). The Effectiveness of E-Learning: An Explorative and Integrative Review of the Definitions, Methodologies and Factors that Promote e-Learning Effectiveness. The Electronic Journal of eLearning, 13(4), 278-290. available online at www.ejel.org.

- Selim, H. M. (2007). Critical success factors for e-learning acceptance: Confirmatory factor models. Computers \& Education, 49(2), 396-413.

- $\quad$ Alkış, N. (2015). The influence of personality traits, motivation and persuasion principles on academic performance (Unpublished Doctoral Dissertation). Middle East Technical University, Ankara.

- Aluçdibi, F., \& Ekici, G. (2012). The effect of biology teachers' classroom management profiles on the biology course motivation level of the high school students. Hacettepe University Journal of Education, 43, $25-36$.

- Kian, T., Yusoff, W., \& Rajah, S. (2014). Motivation for generations' cohorts: An organizational justice perspective. International Journal of Management Sciences, 11(2), 536-542.

- Turan, Z. (2015). The evaluation of flipped classroom method and examination of its effects on academic achievement, cognitive load and motivation (Unpublished Doctoral dissertation). Atatürk University, Erzurum.

- $\quad$ Robbin, S. P., \& Judge, T. A. (2011). Organizational Behavior, 12th ed. New Jersey: Pearson Education.

- $\quad$ Kreitner, R., \& Kinicki, A. (2014). Perilaku Organisasi: Organizational Behavior, Edisi Sembilan Edition. Jakarta: Salemba Empat.

- Singh, H. C., \& Kumar, R. (2012). Role perception of the trainers of Krishi Vigyan Kendras. Ind Res J Ext Edu, 12, 83-86.

- John, F. R. (2017). Situational Factors; The Springer Encyclopedia of Personality and Individuals Differences (EPID); See discussions, stats, and author profiles for this publication at: https://www.researchgate.net/publication/318419421

- Michie, S., Richardson, M., Johnston, M., Abraham, C., Francis, J., Hardeman, W., . . . Wood, C. E. (2013). The behavior change technique taxonomy (v1) of 93 hierarchically clustered techniques: Building an international consensus for the reporting of behavior change interventions. Annals of Behavioral Medicine, 46(1), 81-95.

- Abbott, J. (1994). Learning makes sense: recreating education for a changing future, Letchworth: Education, 2000.

- Aktan, S., \& Tezci, E. (2013). Matematik motivasyon ölçeği (MMÖ) geçerlik ve güvenirlik çalışması. The Journal of Academic Social Science Studies, 6, 57-77.

- Bates, C. C., D’Agostino, J. V., Gambrell, L., \& Xu, M. (2016). Reading recovery: Exploring the effects on first graders' reading motivation and achievement. Journal of Education for Students Placed at Risk, 21, 47-59

- Deepika, S., \& Sushma, S. (2018). Relationship between motivation and academic achievement; International Journal of Advances in Scientific Research. ISSN: 2395-3616 (Online) Journal DOI: https://doi.org/10.7439/ijasr

- Devonish, D., \& Greenidge, D. (2010). The Effect of Organizational Justice on Contextual Performance, Counterproductive Work Behaviors, and Task Performance: Investigating the moderating role of ability-based emotional intelligence. International Journal of Selection and Assessment, 18(1), 75-86.

- Lima, C. C., \& Canbarro, D. (2015). Role perception in the organizational behavior for the organizational innovation accord. Scholedge International Journal Of Management \& Development ISSN, 2394-3378.

- Tang, C. M., \& Chaw, L. Y. (2016). Digital Literacy: A Prerequisite for Effective Learning in a Blended Learning Environment?. Electronic Journal of E-learning, 14(1), 54-65.

- Coldwell, J., Craig, A., Paterson, T., \& Mustard, J. (2008). Online students: Relationships between participation, demographics and academic performance. The Electronic Journal of e-learning, 6(1), 19-30.

- Kumar, P., Kaur, P., \& Kalra, R. K. (2013). Role expectations, role perceptions and role performance of extension personnel. American International Journal of Research in Humanities, Arts and Social Sciences, 4(1), 6-13. Available online at http://www.iasir.net

- Lefevor, G. T., \& Fowers, B. J. (2016). Traits, situational factors, and their interactions as explanations of helping behavior. Personality and Individual Differences, 92, 159-163. 